\title{
Host-parasite interaction: changes in human placental gene expression induced by Trypanosoma cruzi
}

Christian Castillo', Ileana Carrillo', Gabriela Libisch², Natalia Juiz ${ }^{3}$, Alejandro Schijman³ ${ }^{3}$ Carlos Robello ${ }^{2^{*}}$ and Ulrike Kemmerling ${ }^{1 *}$

\begin{abstract}
Background: Chagas disease is caused by Trypanosoma cruzi, a parasite endemic to Latin America. Most infections occur in children by vector or congenital transmission. Trypanosoma cruzi establishes a complexity of specific molecular parasite-host cell interactions to invade the host. However, most studies have been mainly focused on the interaction between the parasite and different cell types, but not on the infection and invasion on a tissue level. During congenital transmission, T. cruzi must cross the placental barrier, composed of epithelial and connective tissues, in order to infect the developing fetus. Here we aimed to study the global changes of transcriptome in the placental tissue after a T. cruzi challenge.
\end{abstract}

Results: Strong changes in gene expression profiling were found in the different experimental conditions, involving the reprogramming of gene expression in genes involved in the innate immune response.

Conclusions: Trypanosoma cruzi induces strong changes in genes involved in a wide range of pathways, especially those involved in immune response against infections.

Keywords: Trypanosoma cruzi, Placenta, Global gene expression, Microarray

\section{Background}

Chagas disease is a zoonotic disease caused by Trypanosoma cruzi, a parasite endemic to Latin America. Most infections occur in children by vector or congenital transmission. The prevalence of Chagas disease in pregnant women in Latin America ranges between 5-40\% depending on the geographical area and the rate of congenital transmission is estimated to be $1-12 \%$ [1]. In addition, due to population mobility, Chagas disease has been increasingly detected in other non-endemic countries and continents (where the vector does not exist) such as the USA, Canada, Australia, Europe and Asia [2, 3]. Congenital transmission, in spite of its low transmission rates, is partially responsible for the progressive globalization of the disease $[2,4,5]$. Importantly, congenital infection is responsible

\footnotetext{
* Correspondence: robello@pasteur.edu.uy; ukemmerling@uchile.cl ${ }^{2}$ Molecular Biology Unit, Pasteur Institute and Departamento de Bioquímica, Facultad de Medicina, Universidad de la República, Montevideo, Uruguay ${ }^{1}$ Programa de Anatomía y Biología del Desarrollo, Instituto de Ciencias Biomédicas, Facultad de Medicina, Universidad de Chile, Santiago, Chile Full list of author information is available at the end of the article
}

for an estimated 22\% of new infections in 2010, making this form of transmission epidemiologically relevant [6].

The parasite presents a complex life-cycle that occurs in both vertebrate and invertebrate hosts, where three major developmental stages are observed: epimastigotes, trypomastigotes and amastigotes. Trypomastigotes constitute the extracellular infective form in mammals where they are able to infect a wide range of nucleated mammalian cells [7]. Interestingly, T. cruzi has co-evolved with mammals to establish a complexity of specific molecular parasite-host cell interactions to invade host cells and tissues, to evade the host immune system and to undergo intracellular replication [8]. Key steps in parasite infection include its host cell penetration and replication of the protozoa in the cytoplasm of infected cells. The application of oligonucleotide and cDNA microarray technologies in the study of host-parasite interactions have permitted rapid and unbiased examination of changes in expression of a large number of genes at the level of transcription $[9,10]$. However, these studies have been mainly 
focused on the interaction between the parasite and different cell types, but not on the infection and invasion on a tissue level.

During congenital transmission, $T$. cruzi must cross the placental barrier in order to infect the developing fetus $[3,11]$. This anatomical barrier is formed by the trophoblast, a two-layer epithelium which is in direct contact with maternal blood, the fetal connective tissue (villous stroma), the endothelium of fetal vessels and the basal laminae that support the epithelia [3, 12]. Interestingly, the congenital transmission rate for $T$. cruzi is low $[4,13]$ and it has been proposed that the placenta might play an important role avoiding parasite infection [3].

The study of gene expression profiles during infection constitutes a very powerful tool to analyze global responses of several kinds of cells and tissues, allowing the identification of new genes and/or pathways implicated in the establishment of the infection and pathogenesis as well as possible local tissue responses [3, 10]. Therefore, here we aimed to study the global changes of transcriptome in the placental tissue after $T$. cruzi challenge.

\section{Methods}

\section{Parasite harvesting}

Trypomastigotes from $T$. cruzi (Y Strain, T. cruzi II) were obtained from previously infected Vero cells (ATCC ${ }^{\circ}$ CCL-81) grown in RPMI medium supplemented with $5 \%$ fetal bovine serum (FBS) and antibiotics (penicillin-streptomycin) at $37^{\circ} \mathrm{C}$ in a humid atmosphere at $5 \% \mathrm{CO}_{2}$. Parasites invaded the cells and replicated intracellularly as amastigotes, after 48-72 h; amastigotes transformed back to trypomastigotes and lysed host cells. The infective trypomastigotes were separated from cellular debris by low speed centrifugation $(500 \times g)$. From the supernatant, the parasites were isolated by centrifugation at $3500 \times g$, suspended in RPMI media (without FBS, 1\% antibiotics; RPMI 1640, Biological Industries Ltd., Kibbutz Beit Haemek, Israel) and quantified in a Neubauer Chamber $[14,15]$.

\section{HPE infection}

HPE were obtained from healthy mothers with uncomplicated pregnancies by cesarean delivery. Placentas were processed in a class II laminar flow hood immediately after delivery. The maternal and fetal surfaces were discarded and villous tissue was obtained from the central part of the cotyledons. The dissected explants were washed with sterile PBS in order to get rid of the blood and co-cultivated with T. cruzi trypomastigotes in serum free RPMI media. HPE were challenged with $10^{5}$ or $10^{6}$ parasites $/ \mathrm{ml}$, since these concentrations have been proposed to correlate with low or high parasitaemia, respectively [16]. For validation experiments, LPS (10 ng/ $\mathrm{ml}$ ) was used as positive control. After 2 or $24 \mathrm{~h}$ of infection (in order to study early and late placental responses [16-18], explants were collected in RNA later solution (Thermo Fisher Scientific, Waltham, Massachusetts, USA), stored at $4{ }^{\circ} \mathrm{C}$ for $24 \mathrm{~h}$ and at $-80{ }^{\circ} \mathrm{C}$ for posterior RNA isolation [19].

\section{RNA purification and microarray experiment}

Total RNA was isolated with a Purelink RNA isolation kit (Thermo Fisher Scientific) according to the manufacturer's instructions. RNA integrity was analyzed with a Bioanalyzer 2100 (Agilent Technologies, Santa Clara, California, USA) obtaining RNA integrity numbers (RIN) above 8 for all samples (on a scale based on an rRNA $28 S / 18 S$ ratio where a RIN of 1 corresponds to a totally degraded RNA and 10 to a totally non-degraded RNA). RNA concentration was quantified by spectrophotometry (Nanodrop, Thermo Fisher Scientific). One hundred nanograms of total RNA was reverse-transcribed into cDNA, then transcribed to cRNA and Cy3-labeled with a Low Input Quick Amp-One Color Labeling Kit (Agilent Technologies). The labeled cRNA was purified with an illustra RNAspin Mini Isolation Kit (GE Healthcare, Little Chalfont, UK) and the total yield was measured with a Qubit RNA HS Kit (Thermo Fisher Scientific). Hybridization, washing, assembling of the chips, and scanning were performed according to the manufacturers' instructions. Briefly, labeled samples were hybridized with SurePrint G3 Human GE 8x60K chips for $17 \mathrm{~h}$ at $60{ }^{\circ} \mathrm{C}$ in an Agilent hybridization oven at $10 \times$ rpm. Posterior washing, stabilization and drying procedures were performed according to Agilent's Low Input Quick Amp Labeling Kit instructions [10].

\section{Data analysis}

Chips were scanned with an Agilent microarray scanner G2565BA; the software Agilent Feature Extraction (version 9.5.1), was used for quality control, data filtering and data normalization. Extracted data from the SurePrintG3 8x60K chips were analyzed using GeneSpring GX 13.0 software. Genes showing a 2-fold change in their expression (or more) with $P \leq 0.05$ were considered differentially expressed using ANOVA and Benjamini-Hochberg false discovery rate correction for multiple testing. Analysis of interaction networks between upregulated genes in each experimental group was performed with Cytoscape network visualization and integration software and GeneMania open-source gene function prediction service plug-in (http://www.genemania.org/) and visualized by the corresponding Cytoscape software version 3.0.2 plug-ins [20] The weighting of the network attributes was set to Gene Ontology (GO)-based weighting for biological processes. Gene set enrichment analysis (GSEA) was performed with GSEA 3.0 software (Broad Institute, Cambridge, Massachussets, USA) [21]. Each gene set permutation was 
Table 1 Sequences of primers used in RT-qPCR

\begin{tabular}{|c|c|c|}
\hline Gene & Forward primer & Reverse primer \\
\hline TLR2 & TCGGAGTTCTCCCAGTGTTTG & GCAGTGAAAGAGCAATGGGC \\
\hline TLR4 & GGTCAGACGGTGATAGCGAG & TTTAGGGCCAAGTCTCCACG \\
\hline TLR7 & TCCATGCCATCAAGAAAGTTGA & GTCTGTGCAGTCCACGATCA \\
\hline TLR9 & CAGCATGGGTITCTGCCG & GGGCAGTTCCACTTGAGGTT \\
\hline NOD1 & CCTGGTGGCCAAGTGATTGTA & CCAAGCCTGCGATTCCCATA \\
\hline NOD2 & ATCCGGAGCCTGTACGAGAT & CGCGCAAATACAGAGCCTTG \\
\hline IL-1 $\beta$ & CTTCGAGGCACAAGGCACAA & CTGGAAGGAGCACTTCATCTGT \\
\hline IL6 & ACCCCCAATAAATATAGGACTGGA & CGAAGGCGCTTGTGGAGAA \\
\hline $\mid L-12 a$ & GCTCCAGAAGGCCAGACAAA & GCCAGAGCCTAAGACCTCAC \\
\hline IFN- & TGGAAAGAGGAGAGTGACAGA & CTGTITAAGCTGCTGGCGAC \\
\hline IL-10 & CGAGATGCCTTCAGCAGAGT & GGCAACCCAGGTAACCCTTA \\
\hline TGF $\beta$ & TACCTGAACCCGTGTTGCTC & CCGGTAGTGAACCCGTTGAT \\
\hline IL-17 & TGGAATCTCCACCGCAATGA & GCTGGATGGGGACAGAGTTC \\
\hline GAPDH & AACAGCGACACCCACTCCTC & GGAGGGGAGATTCAGTGTGGT \\
\hline
\end{tabular}

performed 1000 times, analyses were based on the GO pathways database (http://geneontology.org/) [22] and a normalized enrichment score (NES) was obtained for each gene set. An enrichment map from data obtained with GSEA was generated with the Enrichment Map plug-in for Cytoscape 3.0 [23]. NES and false discovery rate (FDR) q-value were considered as parameters for the analysis. The NES value allows the comparison of analysis results across gene sets because it considers differences in gene sets sizes corrected by the size of the expression dataset; the FDR represents the estimated probability that a gene set with a given NES represents a false positive finding [22].

\section{RT-qPCR}

One hundred picograms of total RNA was retro-transcribed to cDNA using an M-MLV Reverse Transcriptase system with Oligo(dT) primers (Thermo Fisher Scientific). For real-time reactions, $10 \mu \mathrm{l}$ of Sensifast qPCR Master Mix (Bioline, London, UK) was mixed with $100 \mathrm{mM}$ forward

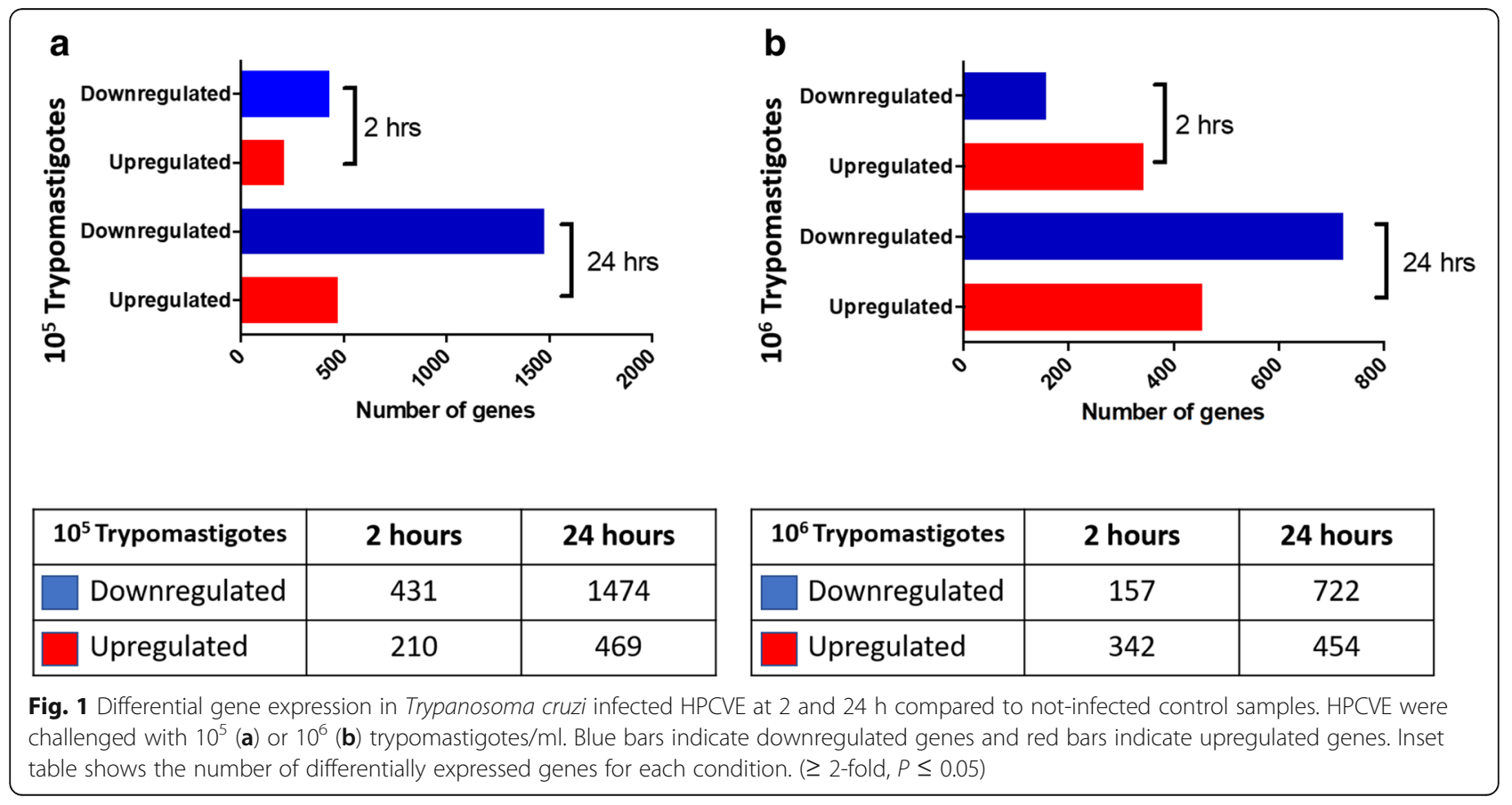


Table 2 Upregulated and downregulated genes with fold change (FC) $\geq 20$ at 2 and 24 h post-infection

\begin{tabular}{|c|c|c|c|c|c|}
\hline Gene ID & Description & FC & Gene ID & Description & FC \\
\hline \multicolumn{6}{|l|}{$2 \mathrm{~h}$} \\
\hline \multicolumn{2}{|c|}{ Upregulated $10^{5}$ trypomastigotes } & \multicolumn{4}{|c|}{ Downregulated $10^{5}$ trypomastigotes } \\
\hline LDOC1 & $\begin{array}{l}\text { Leucine zipper, } \\
\text { downregulated in cancer } 1\end{array}$ & 71.43 & SLC9B1 & $\begin{array}{l}\text { Solute carrier family } 9 \text {, } \\
\text { subfamily B (NHA1, cation } \\
\text { proton antiporter 1), } \\
\text { member } 1\end{array}$ & 65.64 \\
\hline ADAM12 & $\begin{array}{l}\text { ADAM metallopeptidase } \\
\text { domain } 12\end{array}$ & 54.99 & LBP & $\begin{array}{l}\text { Lipopolysaccharide binding } \\
\text { protein }\end{array}$ & 60.23 \\
\hline PNMT & $\begin{array}{l}\text { Phenylethanolamine N- } \\
\text { methyltransferase }\end{array}$ & 51.74 & MEDAG & $\begin{array}{l}\text { Mesenteric estrogen- } \\
\text { dependent adipogenesis }\end{array}$ & 52.12 \\
\hline ADORA3 & Adenosine $\mathrm{A} 3$ receptor & 48.44 & SYT1 & Synaptotagmin I & 49.30 \\
\hline $\mathrm{GH} 2$ & Growth hormone 2 & 44.96 & RGS7BP & $\begin{array}{l}\text { Regulator of G-protein signal- } \\
\text { ing } 7 \text { binding protein }\end{array}$ & 49.08 \\
\hline PCDHB13 & Protocadherin beta 13 & 44.71 & MT1H & Metallothionein $1 \mathrm{H}$ & 47.18 \\
\hline CXCL9 & $\begin{array}{l}\text { Chemokine (C-X-C motif) } \\
\text { ligand } 9\end{array}$ & 26.61 & CAPN8 & Calpain 8 & 46.86 \\
\hline TLR7 & Toll-like receptor 7 & 23.52 & DCD & Dermcidin & 42.36 \\
\hline TLR8 & Toll-like receptor 8 & 21.74 & HTR5A & $\begin{array}{l}\text { 5-hydroxytryptamine } \\
\text { (serotonin) receptor } 5 \mathrm{~A}, \mathrm{G} \\
\text { protein-coupled }\end{array}$ & 42.25 \\
\hline CD46 & $\begin{array}{l}\text { CD46 molecule, } \\
\text { complement regulatory } \\
\text { protein }\end{array}$ & 21.48 & KALRN & Kalirin, RhoGEF kinase & 42.01 \\
\hline C1QTNF3 & $\begin{array}{l}\mathrm{Clq} \text { and tumor necrosis } \\
\text { factor related protein } 3\end{array}$ & 21.41 & $\mathrm{CDH} 18$ & Cadherin 18, type 2 & 35.52 \\
\hline \multicolumn{2}{|c|}{ Upregulated $10^{6}$ trypomastigotes } & \multicolumn{4}{|c|}{ Downregulated $10^{6}$ trypomastigotes } \\
\hline LOC101060810 & Zinc finger protein 98-like & 68.80 & SNRPG & $\begin{array}{l}\text { Small nuclear } \\
\text { ribonucleoprotein } \\
\text { polypeptide G }\end{array}$ & 73.40 \\
\hline LMOD1 & $\begin{array}{l}\text { Leiomodin } 1 \text { (smooth } \\
\text { muscle) }\end{array}$ & 62.19 & TUBA1C & Tubulin, alpha 1c & 71.97 \\
\hline SPIN4 & $\begin{array}{l}\text { Spindlin family, member } \\
4\end{array}$ & 53.45 & TSC22D1 & $\begin{array}{l}\text { TSC22 domain family, } \\
\text { member } 1\end{array}$ & 71.15 \\
\hline LINC00551 & $\begin{array}{l}\text { Long intergenic non- } \\
\text { protein coding RNA } 551\end{array}$ & 52.98 & CD14 & CD14 molecule & 70.98 \\
\hline PSG3 & $\begin{array}{l}\text { Pregnancy specific beta- } \\
\text { 1-glycoprotein } 3\end{array}$ & 47.68 & MBNL2 & $\begin{array}{l}\text { Muscleblind-like splicing } \\
\text { regulator } 2\end{array}$ & 64.74 \\
\hline PSG8 & $\begin{array}{l}\text { Pregnancy specific beta- } \\
\text { 1-glycoprotein } 8\end{array}$ & 45.17 & FUT3 & $\begin{array}{l}\text { Fucosyltransferase } 3 \\
\text { (galactoside 3(4)-L- } \\
\text { fucosyltransferase. Lewis } \\
\text { blood group) }\end{array}$ & 63.73 \\
\hline PSPHP1 & $\begin{array}{l}\text { Phosphoserine } \\
\text { phosphatase pseudogene } \\
1\end{array}$ & 44.87 & GCGR & Glucagon receptor & 62.52 \\
\hline PSG1 & $\begin{array}{l}\text { Pregnancy specific beta- } \\
\text { 1-glycoprotein } 1\end{array}$ & 42.74 & IL6 & $\begin{array}{l}\text { Interleukin } 6 \text { (interferon, } \\
\text { beta 2) }\end{array}$ & 62.25 \\
\hline PCDHB13 & Protocadherin beta 13 & 41.77 & NOG & Noggin & 60.99 \\
\hline HULC & $\begin{array}{l}\text { Hepatocellular carcinoma } \\
\text { upregulated long non- } \\
\text { coding RNA }\end{array}$ & 40.94 & SBSN & Suprabasin & 60.01 \\
\hline ADAMTSL3 & ADAMTS-like 3 & 34.70 & FAM89A & $\begin{array}{l}\text { Family with sequence } \\
\text { similarity } 89 \text {, member A }\end{array}$ & 57.57 \\
\hline
\end{tabular}


Table 2 Upregulated and downregulated genes with fold change (FC) $\geq 20$ at 2 and 24 h post-infection (Continued)

\begin{tabular}{|c|c|c|c|c|c|}
\hline Gene ID & Description & FC & Gene ID & Description & FC \\
\hline \multicolumn{6}{|l|}{$24 \mathrm{~h}$} \\
\hline \multicolumn{2}{|c|}{ Upregulated $10^{5}$ trypomatigotes } & \multicolumn{4}{|c|}{ Downregulated $10^{5}$ trypomastigotes } \\
\hline GCGR & Glucagon receptor & 26.78 & GEMIN2 & $\begin{array}{l}\text { Gem (nuclear organelle) } \\
\text { associated protein } 2\end{array}$ & 66.26 \\
\hline CHRDL2 & Chordin-like 2 & 26.46 & GUCA1A & $\begin{array}{l}\text { Guanylate cyclase activator } \\
1 \mathrm{~A} \text { (retina) }\end{array}$ & 50.37 \\
\hline TAC3 & Tachykinin 3 & 23.82 & LOC340515 & Uncharacterized LOC340515 & 47.71 \\
\hline STC1 & Stanniocalcin 1 & 21.80 & LINC00200 & $\begin{array}{l}\text { Long intergenic non-protein } \\
\text { coding RNA } 200\end{array}$ & 42.88 \\
\hline SLC43A3 & $\begin{array}{l}\text { Solute carrier family } 43 \text {, } \\
\text { member } 3\end{array}$ & 21.60 & FAM182B & $\begin{array}{l}\text { Family with sequence } \\
\text { similarity } 182 \text {, member B }\end{array}$ & 41.35 \\
\hline PENK & Proenkephalin & 21.06 & SEC14L4 & SEC14-like 4 (S. cerevisiae) & 38.81 \\
\hline SLC44A4 & $\begin{array}{l}\text { Solute carrier family } 44, \\
\text { member } 4\end{array}$ & 21.02 & CLEC6A & $\begin{array}{l}\text { C-type lectin domain family } \\
6, \text { member A }\end{array}$ & 38.42 \\
\hline HLA-DQB1 & $\begin{array}{l}\text { Major histocompatibility } \\
\text { complex, class II, DQ } \\
\text { beta } 1\end{array}$ & 20.99 & SNORA65 & $\begin{array}{l}\text { Small nucleolar RNA, H/ACA } \\
\text { box } 65\end{array}$ & 36.94 \\
\hline ANTXR1 & Anthrax toxin receptor 1 & 20.21 & LOC541473 & $\begin{array}{l}\text { FK506 binding protein } 6 \text {, } \\
36 \mathrm{kDa} \text { pseudogene }\end{array}$ & 36.81 \\
\hline SBSN & Suprabasin & 20.18 & AKR7L & $\begin{array}{l}\text { Aldo-keto reductase family 7- } \\
\text { like }\end{array}$ & 36.51 \\
\hline \multicolumn{2}{|c|}{ Upregulated $10^{6}$ trypomastigotes } & \multicolumn{4}{|c|}{ Downregulated $10^{6}$ trypomastigotes } \\
\hline MMP10 & $\begin{array}{l}\text { Matrix metallopeptidase } \\
10 \text { (stromelysin 2) }\end{array}$ & 105.67 & DNMT3L & $\begin{array}{l}\text { DNA (cytosine-5-) } \\
\text {-methyltransferase 3-like }\end{array}$ & 63.39 \\
\hline $\mathrm{CSH} 2$ & $\begin{array}{l}\text { Chorionic } \\
\text { somatomammotropin } \\
\text { hormone } 2\end{array}$ & 68.94 & KLRG2 & $\begin{array}{l}\text { Killer cell lectin-like receptor } \\
\text { subfamily G, member } 2\end{array}$ & 46.45 \\
\hline $\mathrm{GH} 2$ & Growth hormone 2 & 68.66 & MS4A6A & $\begin{array}{l}\text { Membrane-spanning } \\
\text { 4-domains. subfamily A, } \\
\text { member } 6 \text { A }\end{array}$ & 40.49 \\
\hline CCL20 & $\begin{array}{l}\text { Chemokine (C-C motif) } \\
\text { ligand } 20\end{array}$ & 58.87 & TMEM45B & Transmembrane protein 45B & 40.27 \\
\hline ENO2 & $\begin{array}{l}\text { Enolase } 2 \text { (gamma, } \\
\text { neuronal) }\end{array}$ & 53.70 & IGFBP1 & $\begin{array}{l}\text { Insulin-like growth factor } \\
\text { binding protein } 1\end{array}$ & 39.99 \\
\hline SOD2 & $\begin{array}{l}\text { Superoxide dismutase } 2, \\
\text { mitochondrial }\end{array}$ & 53.42 & PSPHP1 & $\begin{array}{l}\text { Phosphoserine phosphatase } \\
\text { pseudogene } 1\end{array}$ & 39.83 \\
\hline PCDHB13 & Protocadherin beta 13 & 53.33 & TPTE2P3 & $\begin{array}{l}\text { Transmembrane } \\
\text { phosphoinositide 3- } \\
\text { phosphatase and Tensin } \\
\text { homolog } 2 \text { pseudogene } 3\end{array}$ & 39.87 \\
\hline SELE & Selectin E & 52.93 & MNDA & $\begin{array}{l}\text { myeloid cell nuclear } \\
\text { differentiation antigen }\end{array}$ & 38.99 \\
\hline $\mathrm{ABO}$ & $\begin{array}{l}\text { ABO blood group } \\
\text { (transferase A, alpha 1-3- } \\
\text { N-acetylgalactosaminyl- } \\
\text { transferase; transferase B, } \\
\text { alpha 1-3- } \\
\text { galactosyltransferase) }\end{array}$ & 51.78 & FGF14-AS2 & FGF14 antisense RNA 2 & 38.98 \\
\hline STC1 & Stanniocalcin 1 & 51.40 & PTX3 & Pentraxin 3, long & 38.59 \\
\hline
\end{tabular}

and reverse primers and $2 \mu \mathrm{l}$ of cDNA. Samples were analyzed in an ABI 7300 real-time PCR system (Applied Biosystems) with an initial step of 3 minutes at $95^{\circ} \mathrm{C}$ for polymerase activation, followed by 40 cycles at $95^{\circ} \mathrm{C}$ for
5 seconds for denaturation, and $60^{\circ} \mathrm{C}$ for 15 seconds for annealing/extension.333. Results were analyzed against human GAPDH as a housekeeping gene and expressed using the $\Delta \Delta C \mathrm{C}$ method (Pfaffl, 2001). The sequences 
of primers can be found in Table 1 . The results were expressed as the mean \pm SD. The significance of differences was evaluated using ANOVA followed by Dunnett's post-hoc test as indicated.

\section{Results}

Trypanosoma cruzi changes the gene expression profile in HPE

The effect of the parasite on placental tissue was assayed in HPE after challenges with a low $\left(10^{5}\right.$ parasites $\left./ \mathrm{ml}\right)$ or a high $\left(10^{6}\right.$ parasites $\left./ \mathrm{ml}\right)$ concentration of trypomastigotes for 2 or $24 \mathrm{~h}$.

Total RNA extracted from infected and non-infected control HPE, was labeled and hybridized to a Human GE $60 \mathrm{~K}$ Microarray, which allows the evaluation of the gene expression profile of 26,083 different human genes. Genes showing at least a 2 -fold change in their expression and a $95 \%$ probability of being differentially expressed $(P \leq 0.05)$ were significantly regulated during parasite challenge. Figure 1 shows the total number of significant differentially expressed genes between infected and non-infected control HPE. A low parasite concentration induces the downregulation of 431 and 1474 genes as well as the upregulation of 210 and 469 genes after 2 and $24 \mathrm{~h}$ of parasite challenge, respectively (Fig. 1a). After a high parasite concentration challenge, 157 and 722 genes were downregulated, and 342 and 454 were upregulated after 2 and $24 \mathrm{~h}$, respectively (Fig. 1b). Major changes occurred after $24 \mathrm{~h}$ of parasite challenge with the lowest parasite concentration. A selection of the most upregulated and downregulated genes (fold change range between 34.70 and 71.43) is shown in Table 2. Among the most upregulated genes are those involved in immune response such as CXCL9, TLR-7, TLR-8, CD46, C1qTNF3, HLA-DQB1 and CCL20; genes involved in extracellular matrix (ECM) remodeling (ADAM12, ADAMTSL3, MMP10) and related to pregnancy. The list of most downregulated genes also includes genes related to immunity such as $L B P, C D 14, D C D$ and $I L-6$.

The Venn diagrams in Fig. 2a show that 19 genes are upregulated in the four different experimental conditions compared to control non-infected samples, which are also shown in the corresponding heatmap (Fig. 2b) listed in Table 3. Contrarily, only 5 genes are downregulated in the same conditions (Fig. 3a, b), which are listed in Table 3. Most of the upregulated genes are related to pregnancy processes.

\section{Trypanosoma cruzi alters a wide range of biological processes in HPE}

GO and pathway analysis were performed using GeneSpringGX 13.0 software (Agilent Technologies), comparing the different experimental conditions described above. Our results indicate that a wide range of biological processes are altered at the different conditions in presence of the parasite (Table 4). The different biological processes detected include immune response, pregnancy related processes and signaling. In order to understand the relationships between those biological processes, we performed a GSEA analysis of gene sets at different times and

\section{a}

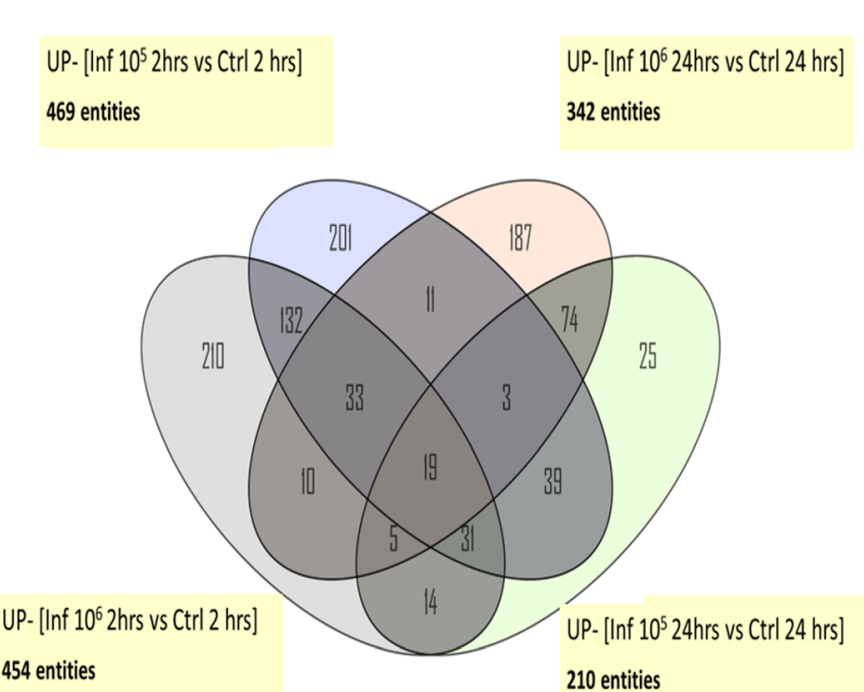

b

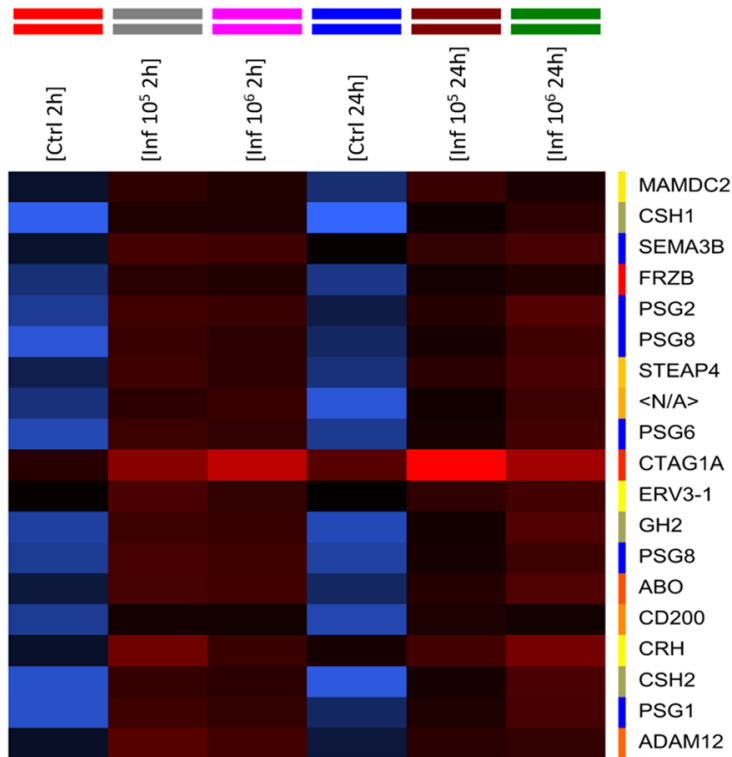

Fig. 2 Venn diagrams comparing common differentially upregulated genes. HPCVE were incubated for 2 and $24 \mathrm{~h}$ with $10^{5}$ or $10^{6}$ T. cruzi trypomastigotes $/ \mathrm{ml}$. All samples were compared to the respective uninfected control. The diagram in a shows the upregulated genes at both parasite concentrations and incubation times, $\mathbf{b}$ corresponds to the heatmap of the differentially expressed genes in the central intersection 
Table 3 Upregulated and downregulated genes in the four different experimental conditions compared to control noninfected samples

\begin{tabular}{|c|c|}
\hline Gene symbol & Description \\
\hline \multicolumn{2}{|c|}{ Upregulated genes } \\
\hline MAMDC2 & Homo sapiens MAM domain containing 2 (MAMDC2), mRNA [NM_153267] \\
\hline $\mathrm{CSH} 1$ & Homo sapiens chorionic somatomammotropin hormone 1 (placental lactogen) (CSH1), mRNA [NM_001317] \\
\hline SEMA3B & $\begin{array}{l}\text { Homo sapiens sema domain, immunoglobulin domain (Ig), short basic domain, secreted, (semaphorin) 3B } \\
\text { (SEMA3B), transcript variant 1, mRNA [NM_004636] }\end{array}$ \\
\hline FRZB & Homo sapiens frizzled-related protein (FRZB), mRNA [NM_001463] \\
\hline PSG2 & Homo sapiens pregnancy specific beta-1-glycoprotein 2 (PSG2), mRNA [NM_031246] \\
\hline PSG8 & Homo sapiens pregnancy specific beta-1-glycoprotein 8 (PSG8), transcript variant 1, mRNA [NM_182707] \\
\hline \multirow[t]{2}{*}{ STEAP4 } & Homo sapiens STEAP family member 4 (STEAP4), transcript variant 2, mRNA [NM_001205315] \\
\hline & Uncharacterized protein [Source: UniProtKB/TrEMBL; Acc: B8ZZY5] [ENST00000409490] \\
\hline PSG6 & Homo sapiens pregnancy specific beta-1-glycoprotein 6 (PSG6), transcript variant 1, mRNA [NM_002782] \\
\hline CTAG1A & Homo sapiens cancer/testis antigen 1A (CTAG1A), mRNA [NM_139250] \\
\hline ERV3-1 & Homo sapiens endogenous retrovirus group 3, member 1 (ERV3-1), mRNA [NM_001007253] \\
\hline $\mathrm{GH} 2$ & Homo sapiens growth hormone 2 (GH2), transcript variant 3, mRNA [NM_022558] \\
\hline PSG8 & Homo sapiens pregnancy specific beta-1-glycoprotein 8 (PSG8), transcript variant 1, mRNA [NM_182707] \\
\hline $\mathrm{ABO}$ & $\begin{array}{l}\text { ABO blood group (transferase A, alpha 1-3-N-acetylgalactosaminyltransferase; transferase B, alpha 1-3- } \\
\text { galactosyltransferase) [Source: HGNC Symbol; Acc:79] [ENST00000319878] }\end{array}$ \\
\hline CD200 & Homo sapiens CD200 molecule (CD200), transcript variant 2, mRNA [NM_001004196] \\
\hline $\mathrm{CRH}$ & Homo sapiens corticotropin releasing hormone (CRH), mRNA [NM_000756] \\
\hline $\mathrm{CSH} 2$ & Homo sapiens chorionic somatomammotropin hormone 2 (CSH2), transcript variant 2, mRNA [NM_022644] \\
\hline PSG1 & Homo sapiens pregnancy specific beta-1-glycoprotein 1 (PSG1), transcript variant 1, mRNA [NM_006905] \\
\hline ADAM12 & Homo sapiens ADAM metallopeptidase domain 12 (ADAM12), transcript variant 2, mRNA [NM_021641] \\
\hline \multicolumn{2}{|c|}{ Downregulated genes } \\
\hline SALL4 & Homo sapiens spalt-like transcription factor 4 (SALL4), mRNA [NM_020436] \\
\hline LINC00200 & Homo sapiens long intergenic non-protein coding RNA 200 (LINC00200), long non-coding RNA [NR_015376] \\
\hline NPPB & Homo sapiens natriuretic peptide B (NPPB), mRNA [NM_002521] \\
\hline TAS2R4 & Homo sapiens taste receptor, type 2, member 4 (TAS2R4), mRNA [NM_016944] \\
\hline STRIP2 & Homo sapiens striatin interacting protein 2 (STRIP2), transcript variant 1, mRNA [NM_020704] \\
\hline FRZB & Homo sapiens frizzled-related protein (FRZB), mRNA [NM_001463] \\
\hline
\end{tabular}

parasite load challenges. We analyzed biological processes pathways based on gene ontology results (Fig. 4). The biggest cluster is composed of pathways related with immune response, followed by development morphogenesis cluster, regulation of metabolic processes and signal transduction genes, metabolic processes, homeostasis, response to stimulus, cell death and endocytosis (Fig. 4).

Several gene sets grouped within the main cluster (immune response), are enriched at 2 or $24 \mathrm{~h}$ post-infection after parasite challenges of $10^{5}$ trypomastigotes $/ \mathrm{ml}$ but not of $10^{6}$ parasites. Thus, immune system process pathways are positively regulated against $10^{5}$ parasites at $2 \mathrm{~h}$ (NES: 1.57; FDR q-value $=0.0013$ ) and $24 \mathrm{~h}$ (NES: 2.75; FDR q-value $=0.0018)$, downregulated with $10^{6}$ trypomastigotes/ml at $2 \mathrm{~h}$ (NES: -2.1 ; FDR q-value $=0.0087$ ) but not at $24 \mathrm{~h}$ (NES: 1.44; FDR q-value $=0.18$ ).
Regulation of immune response is positively regulated with $10^{5}$ parasites at $2 \mathrm{~h}$ (NES: 1,50; FDR q-value = 0.022 ) and $24 \mathrm{~h}$ (NES: 1.98; FDR q-value $=0.01$ ) but negatively with $10^{6}$ parasites at $2 \mathrm{~h}$ (NES: -1,77; FDR q-value $=0.067$ ) and without significant changes at $24 \mathrm{~h}$ (NES: -0,83; FDR q-value not significant).

Gene Ontology process regulation of cytokine production is upregulated $2 \mathrm{~h}$ post-infection (NES: 1.36; FDR q-value $=0.023$ ) but not in the other experimental groups. The inflammatory response pathway is upregulated $24 \mathrm{~h}$ post-infection against $10^{5}$ trypomastigotes (NES: 1.65 ; FDR q-value $=0.049$ ) but downregulated with $10^{6}$ parasites $2 \mathrm{~h}$ post-infection (NES: 1.99; FDR $\mathrm{q}$-value $=0.023)$. Amongst the changes of pathways related to other processes, it can be highlighted the upregulation of cell proliferation pathway $24 \mathrm{~h}$ post-infection 


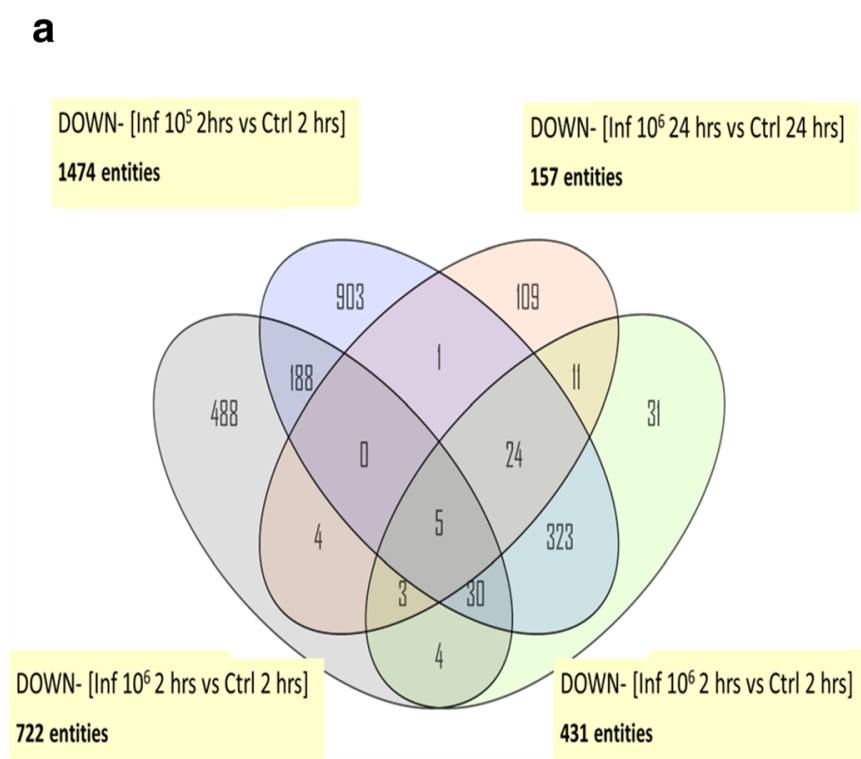

\section{b}

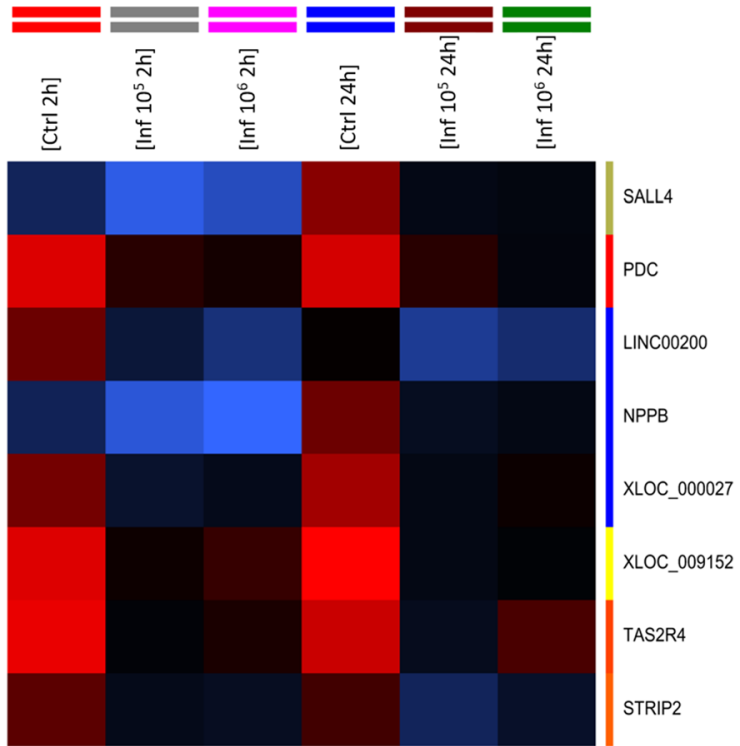

Fig. 3 Venn diagrams comparing common differentially downregulated genes. HPCVE were incubated for 2 and $24 \mathrm{~h}$ with $10^{5}$ or $10^{6} \mathrm{~T}$. cruzi trypomastigotes $/ \mathrm{ml}$. All samples were compared to the respective uninfected control. The diagram in a shows the downregulated genes at both parasite concentrations and incubation times, $\mathbf{b}$ corresponds to the heatmap of the differentially expressed genes in the central intersection

(NES: 2.18; FDR q-value $=0.003)$ and cellular response to hormone stimulus ( $2 \mathrm{~h} 10^{5}$ Trypos NES: 2.53; FDR q-value $=0.005$ )

To understand the nature of the interaction between upregulated or downregulated genes, we performed a gene interaction analysis using the GeneMANIA plug-in for Cytoscape 3.0 software [24, 25]. For each experimental condition, we analyzed co-expression, co-localization, physical interactions, genetic interactions shared protein domains and pathways amongst all the differentially expressed genes $\left(F_{c} \geq 2\right)$ in both upregulated or downregulated gene lists. The relative weight of each process between all interacting genes is depicted in Table 5. In all experimental conditions, co-expression (a category where two genes have similar expression levels) is the predominating interaction, co-localization (genes expressed in the same tissue) the second in the upregulated conditions; however, in downregulated groups physical interactions (when two gene products are found to interact in protein-protein interaction studies) is the second most common interaction. Shared protein domains, genetic and pathways interaction represent marginal interactions in all groups. A circular layout of the interaction network for each is shown in Additional file 1: Figure S1.

\section{Trypanosoma cruzi induces differential expression of pathogen pattern recognition receptors in HPE}

Based on the results of the microarray analysis showing an activation of local immune processes, we decided to validate by RT-qPCR PRR activation and cytokine production. Explants were co-incubated with $10^{5} \mathrm{~T}$. cruzi trypomastigotes for $2 \mathrm{~h}$ and the expression of Toll-like receptors (TLRs) and NOD-like receptors (NLRs) was assayed. Trypanosoma cruzi trypomastigotes induce statistically significant increases of TLR-2 $\left(96.13 \pm 61.6 \% ; F_{(2,9)}=5.409 ; P \leq 0.01\right.$, Fig. 5a), TLR-4 (47.56 $\pm 27.99 \% ; F_{(2,45)}=2.173 ; P \leq 0.0001$, Fig. 5b), TLR-7 (57.29 $\pm 24.59 \% ; F_{(2,2)}=6.048 ; P \leq 0.05$, Fig. 5c) and TLR-9 $\left(61.56 \pm 5.11 \% ; F_{(2,6)}=1.630 ; P \leq 0.01\right.$, Fig. $\left.5 d\right)$ expression compared to non-infected HPE. However, T. cruzi does not increase significantly NOD-1 and NOD-2 receptors (Fig. 5d, e).

\section{Trypanosoma cruzi increases pro-inflammatory and immune-modulating cytokines in HPE}

HPE were co-incubated with $10^{5} \mathrm{~T}$. cruzi trypomastigotes for $2 \mathrm{~h}$ as well as in the presence and absence of LPS as positive controls. T. cruzi induces significant increases of the pro-inflammatory cytokines IL-1 $\beta$ (5542.55 $\pm 1090.11 \% ; F_{(2 \text {, }}$ 19) $=64.91 ; P \leq 0.0001$, Fig. 6a), IL-6 (94.70 $\pm 40.38 \% ; F_{(2,15)}$ $=8.849 ; P \leq 0.01$, Fig. 6b), IL-12 $\alpha\left(77.08 \pm 33.01 \% ; F_{(2,19)}=\right.$ 64.91; $F_{(2,15)}=16.13 ; P \leq 0.01$, Fig. 6c), IFN $\gamma(329.29 \pm$ $162.22 \% ; F_{(2,17)}=7.729 ; P \leq 0.05$, Fig. $\left.6 \mathrm{~d}\right)$ and of the immune-modulating cytokines IL-10 (303.34 $\pm 104.28 \%$; $F_{(2}$, 20) $=14.87 ; P \leq 0.001$, Fig. 6e) and TGF $\beta$ (329.29 \pm $162.22 \% ; F_{(2,11)}=1.684 ; P \leq 0.05$, Fig. 6 f) but not of IL-17 (Fig. 6g).

\section{Discussion}

The interaction between the host and pathogens, including T. cruzi, is the most important factor in determining whether an infection is successful. Host-parasite interaction 
Table 4 Biological processes predicted to be modulated during T. cruzi infection

\begin{tabular}{|c|c|c|c|c|c|}
\hline \multirow[t]{2}{*}{ GO Accession } & \multirow[t]{2}{*}{ GO term } & \multicolumn{4}{|c|}{ No. of genes/condition } \\
\hline & & $10^{5} 2 \mathrm{~h}$ & $10^{6} 2 \mathrm{~h}$ & $10^{5} 24 \mathrm{~h}$ & $10^{6} 24 \mathrm{~h}$ \\
\hline \multicolumn{6}{|l|}{ Upregulated biological processes } \\
\hline GO:0022414 & Reproductive process & 45 & 42 & 45 & 114 \\
\hline GO:0032501|GO:0050874 & Multicellular organismal process & 191 & 189 & 326 & 550 \\
\hline GO:0050896|GO:0051869 & Response to stimulus & 208 & 196 & 728 & 623 \\
\hline GO:0051704|GO:0051706 & Multi-organism process & 56 & 58 & 204 & 197 \\
\hline GO:0065007 & Biological regulation & 269 & 255 & 977 & 836 \\
\hline GO:0002376 & Immune system process & 39 & 36 & 236 & 215 \\
\hline GO:0009987|GO:0008151|GO:0050875 & Cellular process & 346 & 334 & 1161 & 987 \\
\hline GO:0022610 & Biological adhesion & 35 & 23 & 134 & 99 \\
\hline GO:0023052|GO:0023046 & Signaling & 141 & 132 & 543 & 464 \\
\hline GO:0044699 & Single-organism process & 342 & 0 & 1125 & 972 \\
\hline GO:0051179 & Localization & 125 & 0 & 415 & 372 \\
\hline GO:0071840|GO:0071841 & Cellular component organization or biogenesis & 105 & 0 & 427 & 307 \\
\hline GO:0008152 & Metabolic process & 238 & 0 & 0 & 629 \\
\hline GO:0032502 & Developmental process & 144 & 0 & 0 & 434 \\
\hline \multicolumn{6}{|l|}{ Downregulated biological processes } \\
\hline GO:0009987|GO:0008151|GO:0050875 & Cellular processes & 902 & 681 & 937 & 648 \\
\hline GO:0023052|GO:0023046 & Signaling & 388 & 0 & 376 & 0 \\
\hline GO:0032501|GO:0050874 & Multicellular organismal process & 516 & 0 & 490 & 0 \\
\hline GO:0044699 & Single-organism processes & 903 & 620 & 880 & 615 \\
\hline GO:0050896|GO:0051869 & Response to stimulus & 547 & 371 & 507 & 328 \\
\hline GO:0065007 & Biological regulation & 697 & 505 & 734 & 487 \\
\hline GO:0071840|GO:0071841 & Cellular component organization or biogenesis & 0 & 240 & 0 & 248 \\
\hline GO:0022414 & Reproductive processes & 0 & 0 & 106 & 0 \\
\hline GO:0051179 & Localization & 0 & 0 & 275 & 0 \\
\hline GO:0051704|GO:0051706 & Multi-organism processes & 0 & 0 & 123 & 0 \\
\hline
\end{tabular}

includes invasion of the host through primary barriers (such as the placental barrier), evasion of host defenses, pathogen replication in the host, and immunological capacity of the host to control or eliminate the pathogen [26]. Importantly, infected organisms are capable of sensing the intrusion by pathogens and react by triggering host defenses $[17,26]$. On the other hand, the parasite is equipped with multiple tools to establish a long-term relationship with the infected host. Tissue infection in particular is relevant during disease progression. The presence of the parasite provokes tissue damage as well as immune and reparatory responses, which can lead to fibrosis and tissue dysfunction as observed in chagasic cardiomyopathy [27]. Considering the temporary existence of the placenta, the effect on parasite infection on this particular tissue is relevant to understand the physiopathology of congenital transmission in order to obtain tools for diagnosis, prognosis and treatment of the disease.

Previous studies about transcriptomics related to T. cruzi and Chagas disease have been focused on a single type cell response [10,28] or on tissues or organs in animal models $[24,29]$ but not on human tissues. Here, we describe for the first time, the transcriptomics of an ex vivo human placental tissue model in response to challenges with the parasite.

As expected, T. cruzi modifies an ample range of biological processes during tissue invasion and infection. As described before, the parasite dramatically changes the gene expression in single cells [10]. However, in tissue and organ samples a more complex change in gene expression can be expected since they are composed of different cell types or tissues. For instance, in HPE epithelial cells derived from the trophoblast and fetal capillaries as well as fibroblasts and macrophages in the fetal connective tissue can be found, between others [3]. In addition, ECM components, that are synthetized by the resident cells are also present in tissue and organ samples $[18,19]$. Similar results have been obtained in animal models, where important changes in murine myocardium metabolic pathways [29] and in murine placental response [24] are described. The increase of 


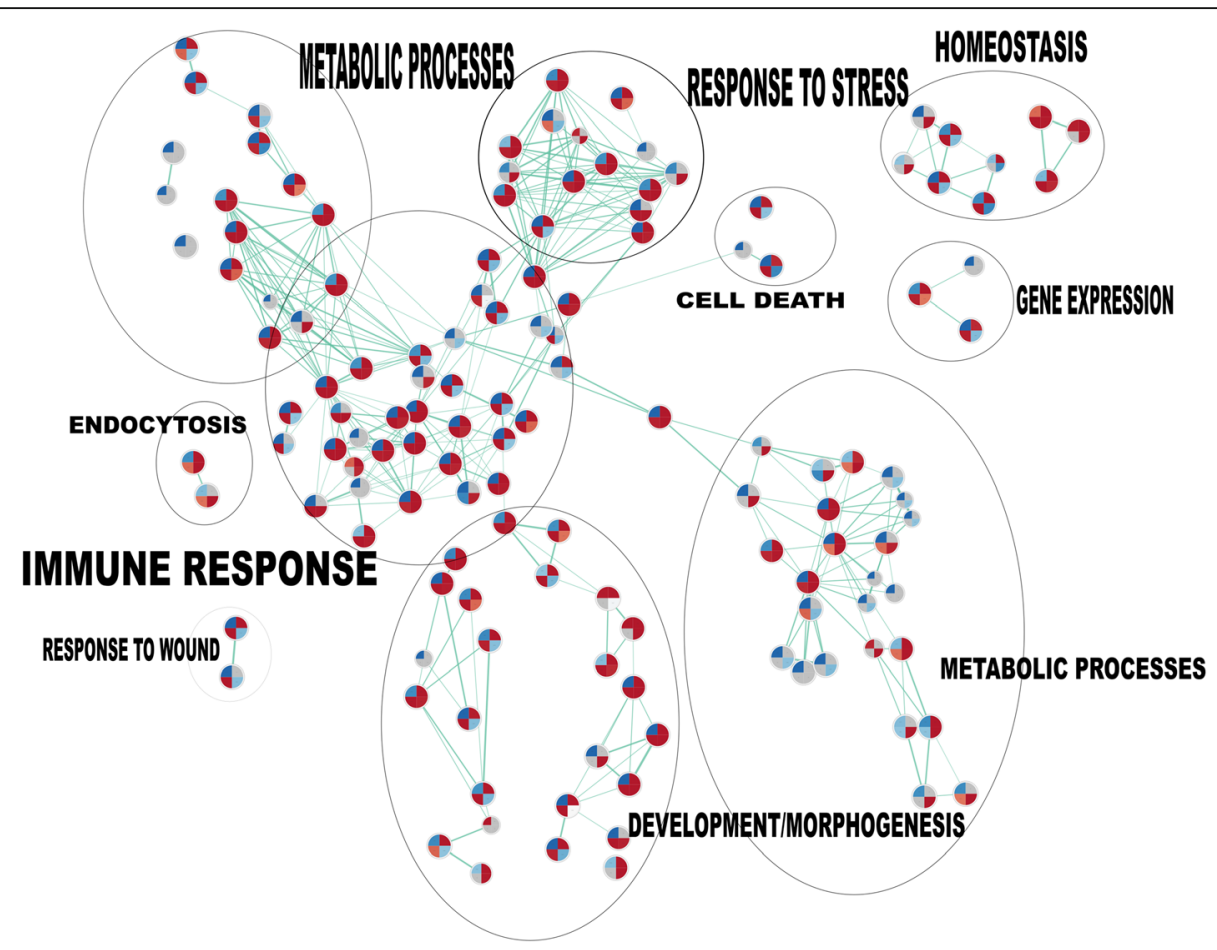

Fig. 4 Enrichment map of gene sets of biological processes pathways. HPCVE were incubated for 2 and $24 \mathrm{~h}$ with $10^{5}$ or $10^{6} \mathrm{~T}$. cruzi trypomastigotes/ml. Genes with fold changes $\geq 2$ ( $P \leq 0.05)$ were considered for the analysis. Gene set analysis (GSEA) was performed based in pathways from GO biological processes. Nodes correspond to gene sets and connecting lines to overlapping member genes between nodes. Divided circles represent predicted pathways, each segment of the circle represents a different experimental group according to attached legend and colors depict upregulated (red) or downregulated (blue) genes. Clusters grouped by biological function were manually labeled

gene expression of proteases involved in ECM-remodeling (Table 2) is in concordance with our previous results showing that the parasite increased expression and activity of matrix metalloproteases (MMP-2 and MMP-9) in human placenta [19]. The profound changes in genes involved in signaling agrees with numerous previous studies that showed that $T$. cruzi activates or inhibits several signal transduction pathways $[14,28,30]$.
The effect of $T$. cruzi on the immune system responses are particularly relevant since they are our main defense against the pathogen. The parasite dramatically changes host genes involved in the immune response. The expression of an important number of genes of innate immunity is increased. Thus, genes related to complement regulation and function such as CD46 and C1q are upregulated. We have previously shown, that during ex

Table 5 Relative weight of gene interactions in T. cruzi-infected HPE

\begin{tabular}{|c|c|c|c|c|c|c|c|c|}
\hline Network group & $\begin{array}{l}2 \mathrm{~h} / 10^{5} \\
\text { Up }\end{array}$ & $\begin{array}{l}2 \mathrm{~h} / 10^{5} \\
\text { Down }\end{array}$ & $\begin{array}{l}2 \mathrm{~h} / 10^{6} \\
\text { Up }\end{array}$ & $\begin{array}{l}2 \mathrm{~h} / 10^{6} \\
\text { Down } \\
\end{array}$ & $\begin{array}{l}24 \mathrm{~h} / 10^{5} \\
\text { Up }\end{array}$ & $\begin{array}{l}24 \mathrm{~h} / 10^{5} \\
\text { Down }\end{array}$ & $\begin{array}{l}24 \mathrm{~h} / 10^{6} \\
\text { Up }\end{array}$ & $\begin{array}{l}24 \mathrm{~h} / 10^{6} \\
\text { Down }\end{array}$ \\
\hline Co-expression & 72 & 61 & 64 & 42 & 75 & 66 & 75 & 75 \\
\hline Co-localization & 13 & 7 & 18 & 9 & 11 & 6 & 14 & 3 \\
\hline Physical interactions & 7 & 14 & 11 & 31 & 6 & 17 & 6 & 9 \\
\hline Genetic interactions & 4 & 0 & 2 & 4 & 3 & 0 & 0 & 1 \\
\hline Shared protein domains & 0 & 1 & 1 & 3 & 0 & 1 & 1 & 0 \\
\hline Pathway & 0 & 1 & 1 & 3 & 0 & 0 & 1 & 7 \\
\hline Others & 4 & 16 & 3 & 8 & 5 & 10 & 3 & 5 \\
\hline
\end{tabular}

Abbreviations: Up, upregulated; Down, downregulated; $\mathrm{H}$, hours of HPE incubation with the parasite; $10^{5}$, challenge with $10^{5}$ parasites $/ \mathrm{ml} ; 10^{6}$, challenge with $10^{6}$ parasites/ml 

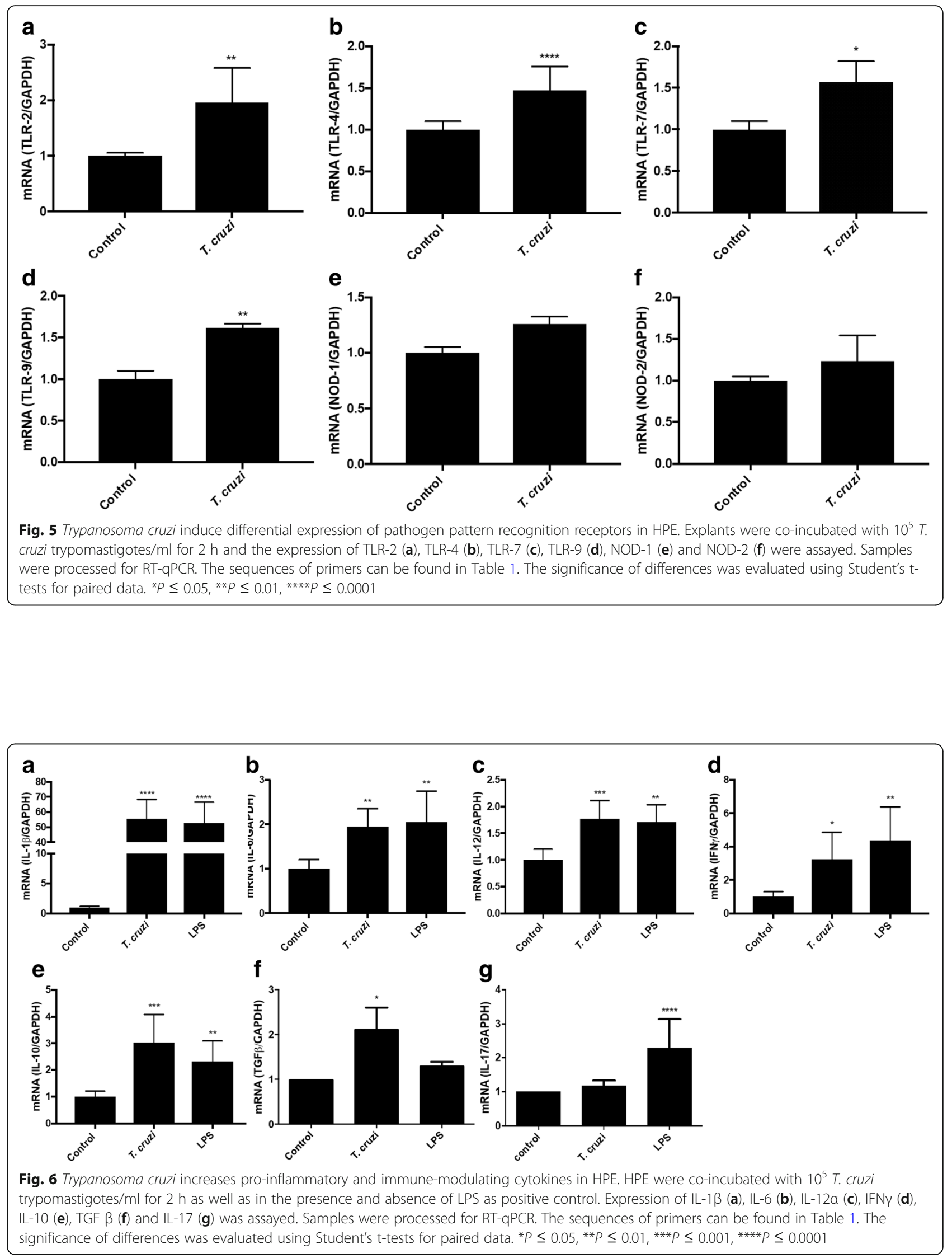
vivo infection of HPE, T. cruzi calreticulin (TcCRT) acts as a virulence factor since it binds maternal classical complement component $\mathrm{C} 1 \mathrm{q}$ and increases parasite infectivity [31]. On the other hand, TLRs are also increased, particularly TLR-7 and TLR- 8 which are increased over 20 -fold. The validation experiments show that both mentioned TLRs as well as TLR-2, TLR-4 and TLR-9 are significantly increased (Fig. 5). However, TLR-2, the TLR whose inhibition increases parasite infection in HPE as well as parasite-induced tissue damage [17] showed no significant increase in the microarray analysis (Additional file 1: Figure S1).

A similar contradictory result was obtained with IL-6; a high parasite concentration decreases the expression of this cytokine more than 60-fold (Table 2). However, a low parasite concentration does not change IL-6 expression (Additional file 1: Figure S1). However, our RT-qPCR data show a significant increase of IL-6 (Fig. 5) that is in concordance with the increase of IL- 6 protein in the culture media of HPE after parasite challenge in the same condition [17], suggesting regulation at post-transcriptional levels.

Another important group of genes that change their expression are those related to pregnancy. Most of the 19 upregulated genes in the four different experimental conditions compared to control samples are related to pregnancy processes (Table 3) and to the maintenance and development of the fetus such as pregnancy specific beta-1-glycoproteins, GH2 (growth hormone 2), CSH1 and $\mathrm{CSH} 2$ (chorionic somatomammotropin hormone 1 and 2). Given that the placenta is the sole interface between mother and fetus and that this organ not only protects the fetus from infection but also regulates important metabolic and other physiological processes [32], it appears easily explainable that different pregnancy related processes are affected.

\section{Conclusions}

Trypanosoma cruzi induces strong changes in genes involved in a wide range of pathways, especially those involved in immune response against infections.

\section{Additional file}

Additional file 1: Figure S1. Interaction networks in differentially expressed genes from each experimental group. HPCVE were incubated during 2 and $24 \mathrm{~h}$ with $10^{5}$ or $10^{6} \mathrm{~T}$. cruzi trypomastigotes. Interaction networks from differentially expressed genes $(F C \geq 2)$ compared with uninfected control with GeneMANIA function prediction service plug-in in Cytoscape software. Co-expression, co-localization, physical interactions, genetic interactions shared protein domains and pathways are shown and each color represents specific interactions according to legend. (PDF $707 \mathrm{~kb}$ )

\section{Funding}

This work was supported by ERANET-LAC grant ELAC2014/HID-0328 (to UK and AGS), REDES130118 (to UK and CR), UREDES URC-024/16 (to UK) and FONDECYT 3180452 (to ChC).

\section{Availability of data and materials}

The datasets generated during and analyzed during the current study are available in the GEO repository under the accession number GSE113155.

\section{Authors' contributions}

UK, CR and ChC conceived and designed the experiments. ChC, GL, IC and NJ performed the experiments. ChC, GL, IC, CR, AS and UK analyzed the data. $\mathrm{ChC}, \mathrm{AJ}$ and UK wrote the manuscript. All authors read and approved the final manuscript.

Ethics approval and consent to participate

This study was conducted in accordance with Ethic Committee of the Faculty of Medicine, University of Chile (No. 041-2011). Each patient signed an informed consent for experimental use.

Consent for publication

Not applicable.

Competing interests

The authors declare that they have no competing interests.

\section{Publisher's Note}

Springer Nature remains neutral with regard to jurisdictional claims in published maps and institutional affiliations.

\section{Author details}

'Programa de Anatomía y Biología del Desarrollo, Instituto de Ciencias Biomédicas, Facultad de Medicina, Universidad de Chile, Santiago, Chile. ${ }^{2}$ Molecular Biology Unit, Pasteur Institute and Departamento de Bioquímica, Facultad de Medicina, Universidad de la República, Montevideo, Uruguay. ${ }^{3}$ Instituto de Investigaciones en Ingeniería Genética y Biología Molecular "Dr. Héctor Torres", Buenos Aires, Argentina.

Received: 16 April 2018 Accepted: 2 July 2018

Published online: 24 August 2018

\section{References}

1. Moscatelli G, Moroni S, Garcia-Bournissen F, Ballering G, Bisio M, Freilij H, et al. Prevention of congenital Chagas through treatment of girls and women of childbearing age. Mem Inst Oswaldo Cruz. 2015;110:507-9.

2. Schmunis G. Epidemiology of Chagas disease in non-endemic countries: the role of international migration. Mem Inst Oswaldo Cruz. 2007;102:75-85.

3. Liempi A, Castillo C, Carrillo I, Munoz L, Droguett D, Galanti N, et al. A local innate immune response against Trypanosoma cruzi in the human placenta: the epithelial turnover of the trophoblast. Microb Pathog. 2016;99:123-9.

4. Perez-Molina JA, Perez AM, Norman FF, Monge-Maillo B, Lopez-Velez R. Old and new challenges in Chagas disease. Lancet Infect Dis. 2015;15:1347-56.

5. Castillo C, Munoz L, Carrillo I, Liempi A, Medina L, Galanti N, et al. Toll-like receptor-2 mediates local innate immune response against Trypanosoma cruzi in ex vivo infected human placental chorionic villi explants. Placenta. 2017;60:40-6

6. Kaplinski M, Jois M, Galdos-Cardenas G, Rendell VR, Shah V, Do RQ, et al. Sustained domestic vector exposure is associated with increased Chagas cardiomyopathy risk but decreased parasitemia and congenital transmission risk among young women in Bolivia. Clin Infect Dis. 2015;61:918-26.

7. Barrias ES, de Carvalho TM, De Souza W. Trypanosoma cruzi: entry into mammalian host cells and parasitophorous vacuole formation. Front Immunol. 2013:4:186.

8. Walker DM, Oghumu S, Gupta G, McGwire BS, Drew ME, Satoskar AR. Mechanisms of cellular invasion by intracellular parasites. Cell Mol Life Sci. 2014:71:1245-63.

9. Shigihara T, Hashimoto M, Shindo N, Aoki T. Transcriptome profile of Trypanosoma cruzi-infected cells: simultaneous up- and down-regulation of proliferation inhibitors and promoters. Parasitol Res. 2008;102:715-22.

10. Chiribao ML, Libisch G, Parodi-Talice A, Robello C. Early Trypanosoma cruzi infection reprograms human epithelial cells. Biomed Res Int. 2014;2014:439501. 
11. Carlier $Y$, Truyens C, Deloron P, Peyron F. Congenital parasitic infections: a review. Acta Trop. 2012;121:55-70.

12. Arora N, Sadovsky Y, Dermody TS, Coyne CB. Microbial vertical transmission during human pregnancy. Cell Host Microbe. 2017;21:561-7.

13. Rendell VR, Gilman RH, Valencia E, Galdos-Cardenas G, Verastegui M, Sanchez L, et al. Trypanosoma cruzi-infected pregnant women without vector exposure have higher parasitemia levels: implications for congenital transmission risk. PLoS One. 2015;10:e0119527.

14. Castillo C, Villarroel A, Duaso J, Galanti N, Cabrera G, Maya JD, et al. Phospholipase $\mathrm{C}$ gamma and ERK1/2 mitogen activated kinase pathways are differentially modulated by Trypanosoma cruzi during tissue invasion in human placenta. Exp Parasitol. 2013;133:12-7.

15. Liempi A, Castillo C, Duaso J, Droguett D, Sandoval A, Barahona K, et al. Trypanosoma cruzi induces trophoblast differentiation: a potential local antiparasitic mechanism of the human placenta? Placenta. 2014;35:1035-42.

16. Fretes RE, Kemmerling U. Mechanism of Trypanosoma cruzi placenta invasion and infection: the use of human chorionic villi explants. J Trop Med. 2012;2012:614820.

17. Castillo C, Munoz L, Carrillo I, Liempi A, Gallardo C, Galanti N, et al. Ex vivo infection of human placental chorionic villi explants with Trypanosoma cruzi and Toxoplasma gondii induces different Toll-like receptor expression and cytokine/chemokine profiles. Am J Reprod Immunol. 2017. https://doi.org/ 10.1111/aji.12660.

18. Duaso J, Rojo G, Cabrera G, Galanti N, Bosco C, Maya JD, et al. Trypanosoma cruzi induces tissue disorganization and destruction of chorionic villi in an ex vivo infection model of human placenta. Placenta. 2010:31:705-11.

19. Castillo C, Lopez-Munoz R, Duaso J, Galanti N, Jaña F, Ferreira J, et al. Role of matrix metalloproteinases 2 and 9 in ex vivo Trypanosoma cruzi infection of human placental chorionic villi. Placenta. 2012;33:991-7.

20. Shannon P, Markiel A, Ozier O, Baliga NS, Wang JT, Ramage D, et al. Cytoscape: a software environment for integrated models of biomolecular interaction networks. Genome Res. 2003;13:2498-504.

21. Subramanian A, Tamayo P, Mootha VK, Mukherjee S, Ebert BL, Gillette MA, et al. Gene set enrichment analysis: a knowledge-based approach for interpreting genome-wide expression profiles. Proc Natl Acad Sci USA. 2005; 102:15545-50

22. Juiz NA, Torrejon I, Burgos M, Fernanda Torres AM, Duffy T, Cayo NM, et al. Alterations in placental gene expression of pregnant women with chronic Chagas disease. Am J Pathol. 2018:188:1345-53.

23. Merico D, Isserlin R, Stueker O, Emili A, Bader GD. Enrichment map: a network-based method for gene-set enrichment visualization and interpretation. PLoS One. 2010;5:e13984.

24. Juiz NA, Solana ME, Acevedo GR, Benatar AF, Ramirez JC, da Costa PA, et al. Different genotypes of Trypanosoma cruzi produce distinctive placental environment genetic response in chronic experimental infection. PLoS Negl Trop Dis. 2017;11:e0005436.

25. Montojo J, Zuberi K, Rodriguez H, Bader GD, Morris Q. GeneMANIA: Fast gene network construction and function prediction for Cytoscape. F1000Res. 2014;3:153.

26. Sen R, Nayak L, De RK. A review on host-pathogen interactions: classification and prediction. Eur J Clin Microbiol Infect Dis. 2016:35:1581-99.

27. Nagajyothi F, Machado FS, Burleigh BA, Jelicks LA, Scherer PE, Mukherjee $S$, et al. Mechanisms of Trypanosoma cruzi persistence in Chagas disease. Cell Microbiol. 2012;14:634-43.

28. Li Y, Shah-Simpson S, Okrah K, Belew AT, Choi J, Caradonna KL, et al. Transcriptome remodeling in Trypanosoma cruzi and human cells during intracellular infection. PLoS Pathog. 2016;12:e1005511.

29. Girones N, Carbajosa S, Guerrero NA, Poveda C, Chillon-Marinas C, Fresno M. Global metabolomic profiling of acute myocarditis caused by Trypanosoma cruzi infection. PLoS Negl Trop Dis. 2014:8:e3337.

30. Maeda FY, Cortez C, Yoshida N. Cell signaling during Trypanosoma cruzi invasion. Front Immunol. 2012:3:361.

31. Castillo C, Ramirez G, Valck C, Aguilar L, Maldonado I, Rosas C, et al. The interaction of classical complement component $\mathrm{C} 1$ with parasite and host calreticulin mediates Trypanosoma cruzi infection of human placenta. PLoS Negl Trop Dis. 2013;7:e2376.

32. Mayhew TM. Turnover of human villous trophoblast in normal pregnancy: what do we know and what do we need to know? Placenta. 2014;35:229-40.

\section{Ready to submit your research? Choose BMC and benefit from:}

- fast, convenient online submission

- thorough peer review by experienced researchers in your field

- rapid publication on acceptance

- support for research data, including large and complex data types

- gold Open Access which fosters wider collaboration and increased citations

- maximum visibility for your research: over $100 \mathrm{M}$ website views per year

At BMC, research is always in progress.

Learn more biomedcentral.com/submissions 